\title{
Genetic diversity of Lagerstroemia (Lythraceae) species assessed by simple sequence repeat markers
}

\author{
D. He ${ }^{1}$, Y. Liu ${ }^{1}$, M. Cai ${ }^{1}$, H.T. Pan ${ }^{1,2}$, Q.X. Zhang ${ }^{1,2}$, X.Y. Wang ${ }^{1}$ and \\ X.J. Wang ${ }^{1}$ \\ ${ }^{1}$ Department of Ornamental Horticulture, College of Landscape Architecture, \\ Beijing Forestry University, Beijing, China \\ ${ }^{2}$ China National Engineering Research Center for Floriculture, \\ Beijing Forestry University, Beijing, China \\ Corresponding authors: H.T. Pan / Q.X. Zhang \\ E-mail: htpan2000@yahoo.com.cn / zqx@bjfu.edu.cn
}

Genet. Mol. Res. 11 (3): 3522-3533 (2012)

Received December 20, 2011

Accepted March 15, 2012

Published September 26, 2012

DOI http://dx.doi.org/10.4238/2012.September.26.9

\begin{abstract}
Lagerstroemia (crape myrtle) are famous ornamental plants with large pyramidal racemes, long flower duration, and diverse colors. However, little is known about the genetic structure and diversity of germplasm in Lagerstroemia. We genotyped $81 \mathrm{~L}$. indica cultivars, five other species of Lagerstroemia, and 10 interspecific hybrids using 30 simple sequence repeat markers; 275 alleles were generated with a mean of nine alleles per locus. The mean polymorphism information content value, a measure of gene diversity, was 0.63 , with a range from 0.25 to 0.86 . The mean observed heterozygosity $(0.51)$ tended to be lower than the mean expected heterozygosity $(0.67)$. The mean F-statistics $\left(F_{\mathrm{ST}}, F_{\mathrm{IS}}\right.$, and $\left.F_{\mathrm{IT}}\right)$ were $0.05,0.20$, and 0.24 , respectively, indicating a high level of genetic variation among cultivars. Clustering analysis based on genetic distance divided the 96 genotypes into three distinct groups, which corresponded with their genetic backgrounds and geographic regions. $L$. indica cultivars and the other five $L$. species were grouped into different sub-clusters. Chinese and North American cultivars were divided into different clusters. These data about the genetic relationship among cultivars demonstrated the potential value of $L$. indica cultivars and
\end{abstract}


other Lagerstroemia species for widening the genetic basis of breeding programs for this ornamental flower.

Key words: Lagerstroemia; SSR; Genetic diversity; Cluster analysis

\section{INTRODUCTION}

Lagerstroemia is a member of the family Lythraceae and comprises more than 50 species that are native to southeastern Asia and Australia (Brickell, 1996). Lagerstroemia indica, native to Southeast Asia, is a medium to large shrub with brown bark, glabrous trunk, and deciduous leaves that change from green to yellow, orange, or red in the fall (Wang et al., 2010). In China, L. indica has been widely cultivated in gardens for about 1800 years (Zhang, 1991).

Many new cultivars with colorful flowers, different growth habits, and disease resistance had been cultivated since the 1960s (Egolf, 1967, 1981, 1987, 1990; Pooler, 2006). L. fauriei, L. speciosa, L. limii, and L. subcostata have been introduced in crape myrtle breeding programs (Pooler, 2003; Pounders, 2007). L. fauriei, from central and southern Japan, is a very important species, partly for its special landscape performance and strong resistance to mildew diseases. In fact, a series of crape myrtle cultivars with colorful flowers, beautiful fall leaves and high mildew resistance were found to be hybrids of L. fauriei (Egolf and Andrick, 1978; Egolf, 1986). L. speciosa, native to South East Asia, India and the Philippines, has large flowers and is widely cultivated as an ornamental tree in tropical and subtropical areas. L. limii and $L$. subcostata are usually trees of about 4 to $14 \mathrm{~m}$ high and have smaller flowers. L. caudata has smaller, fragrant white flowers, blooms earlier than L. indica, and has been used to breed earlyflowering and fragrant crape myrtle hybrid cultivars since 2008 (Cai et al., 2010).

Compared to traditional morphological traits, molecular markers are not influenced by the environment and reflect the real genetic diversity. They do not require previous pedigree information (Bohn et al., 1999). There are various types of molecular markers for genome analysis, among which simple sequence repeats (SSRs) are abundant, co-dominant, multiallelic, highly polymorphic, and chromosome-specific. SSRs have been extensively used in genetic diversity studies in many plants, including Citrus (Barkley et al., 2006), Theobroma cacao (Sereno et al., 2006), Malus sieversii (Zhang et al., 2007), Trifolium pretense (Dias et al., 2008), and Jatropha curcas (Subramanyam et al., 2009).

The first investigation of the genetic diversity of Lagerstroemia was on 12 L. fauriei clones using AFLP and RAPD markers by Pooler (2003). Recently, SSRs have been used to estimate genetic diversity among Lagerstroemia species and cultivars (Rinehart and Pounders, 2010; Wang et al., 2011; Cai et al., 2011). However, there has been no report on genetic diversity of crape myrtle cultivars from different geographic regions. The objectives of our study were 1) to evaluate the genetic diversity among Lagerstroemia species and cultivars using SSR markers and 2) to compare genetic backgrounds and evaluate the possibility of collecting cultivars from different regions for crape myrtle breeding.

\section{MATERIAL AND METHODS}

\section{Sampling of species and cultivars}

A total of 96 genotypes, including five species (L. speciosa, L. subcostata, L. limii, L. 
fauriei, and L. caudata), 81 L. indica cultivars, and 10 interspecific hybrids (Table 1), were used in our study. Among these accessions, 55 cultivars were introduced from North America and four cultivars from Europe. The other 22 cultivars were all from China, and the five Lagerstroemia species have been cultivated in China for many years. The 10 interspecific hybrids are from the crosses of L. caudata $\times$ L. indica and L. indica $\times$ L. speciosa and were created by our research group in 2008. The list of cultivars and species, with their plant size, flower color, genetic background, and their possible geographic regions, are listed in Table 1. All of these cultivars and species were cultivated as ornamental plant germplasm at the China National Engineering Research Center for Floriculture in Beijing.

Table 1. The detailed information of Lagerstroemia L. used in this study.

\begin{tabular}{|c|c|c|c|c|c|}
\hline No. & Cultivars/line name & Plant size & Genetic background & Flower color (RHS) & Region \\
\hline 1 & Tuscarora & Tree & L. indica $3 / 4$, L. fauriei $1 / 4$ & Red Purple 71B & NA \\
\hline 2 & Muskogee & Tree & L. indica $1 / 2$, L. fauriei $1 / 2$ & Red Purple 63C & NA \\
\hline 3 & Tuskegee & Tree & L. indica $3 / 4$, L. fauriei $1 / 4$ & Red Purple 61C & NA \\
\hline 4 & Choctaw & Tree & L. indica $3 / 4$, L. fauriei $1 / 4$ & Red Purple 68C & NA \\
\hline 5 & Dallas Red & Shrub & L. indica & Red 53B & NA \\
\hline 6 & Carolina Red & Shrub & L. indica & Red 46B & NA \\
\hline 7 & Sarah Favorite & Tree & L. indica $1 / 2$, L. fauriei $1 / 2$ & White NN155C & NA \\
\hline 8 & Miami & Tree & L. indica $5 / 8$, L. fauriei $3 / 8$ & Red 55C & NA \\
\hline 9 & Biloxi & Tree & L. indica $1 / 2$, L. fauriei $1 / 2$ & Red Purple 63B & NA \\
\hline 10 & Natchez & Shrub & L. indica $1 / 2$, L. fauriei $1 / 2$ & Red Purple 65A & NA \\
\hline 11 & Catawba & Shrub & L. indica & Red Purple 72A & NA \\
\hline 12 & Osage & Tree & L. indica $1 / 2$, L. fauriei $1 / 2$ & Red Purple 68B & NA \\
\hline 13 & Sioux & Tree & L. indica $3 / 4$, L. fauriei $1 / 4$ & Red Purple 68B & NA \\
\hline 14 & Comanche & Tree & L. indica $3 / 4$, L. fauriei $1 / 4$ & Red Purple N66A & NA \\
\hline 15 & Queens Lace & Dwarf & L. indica & Red 53B and White NN155C & NA \\
\hline 16 & Yuma & Tree & L. indica $3 / 8$, L. fauriei $3 / 8$, L. amabilis $1 / 4$ & Purple 76A & NA \\
\hline 17 & Lipan & Tree & L. indica $5 / 8$, L. fauriei $3 / 8$ & Red Purple 72B & NA \\
\hline 18 & Centennial Spirit & Shrub & L. indica & Red Purple 58A & NA \\
\hline 19 & William Toovey & Tree & L. indica & Red Purple N66B & NA \\
\hline 20 & Pecos & Shrub & L. indica $1 / 2$, L. fauriei $1 / 2$ & Red Purple 72B & NA \\
\hline 21 & Okmulgee & Dwarf & L. indica & Red 47A & NA \\
\hline 22 & Acoma & Shrub & L. indica $3 / 4$, L. fauriei $1 / 4$ & White NN155C & NA \\
\hline 23 & Hopi & Shrub & L. indica $3 / 4$, L. fauriei $1 / 4$ & Red Purple 68A & NA \\
\hline 24 & Victor & Shrub & L. indica & Red Purple 63A & NA \\
\hline 25 & Near East & Shrub & L. indica & Red Purple N66A & EA \\
\hline 26 & Zuni & Shrub & L. indica $3 / 4$, L. fauriei $1 / 4$ & Purple N78A & NA \\
\hline 27 & Centennial & Shrub & L. indica & Purple N78A & NA \\
\hline 28 & Prairie Lace & Shrub & L. indica & Red 52A and White NN155C & NA \\
\hline 29 & Tonto & Shrub & L. indica $3 / 4$, L. fauriei $1 / 4$ & Red Purple 61B & NA \\
\hline 30 & Velma's Royal Delight & Shrub & L. indica & Red Purple 72A & NA \\
\hline 31 & Caddo & Shrub & L. indica, L. fauriei & Red Purple 58C & NA \\
\hline 32 & Powhatan NEW & Shrub & L. indica & Purple N78D & NA \\
\hline 33 & New Orleans & Shrub & L. indica & Purple N78B & NA \\
\hline 34 & Sacramento & Dwarf & L. indica & Red Purple 67B & NA \\
\hline 35 & Delta Blush & Shrub & L. indica & Red Purple 68A & NA \\
\hline 36 & Pink Blush & Shrub & L. indica & Red Purple 63D and 68B & NA \\
\hline 37 & Lafayette & Shrub & L. indica & Purple 76B & NA \\
\hline 38 & World's Fair & Dwarf & L. indica & Red Purple 68A & NA \\
\hline 39 & Houston NEW & Dwarf & L. indica & Red Purple 67C & NA \\
\hline 40 & Pixie White & Dwarf & L. indica & White NN155C & NA \\
\hline 41 & Mardi Gras & Shrub & L. indica & Purple Violet N80B & NA \\
\hline 42 & Baton Rouge & Dwarf & L. indica & Red Purple 63A & NA \\
\hline 43 & Bourbon Street & Dwarf & L. indica & Red Purple 61D & NA \\
\hline 44 & Bayou Marie & Dwarf & L. indica & Red Purple 68B & NA \\
\hline 45 & Creole & Dwarf & L. indica & Red Purple 63B & NA \\
\hline 46 & Cordon Bleu & Dwarf & L. indica & Purple 76A & NA \\
\hline 47 & Bicolor & Shrub & L. indica & Red Purple N66B and White NN155C & NA \\
\hline
\end{tabular}

Continued on next page 


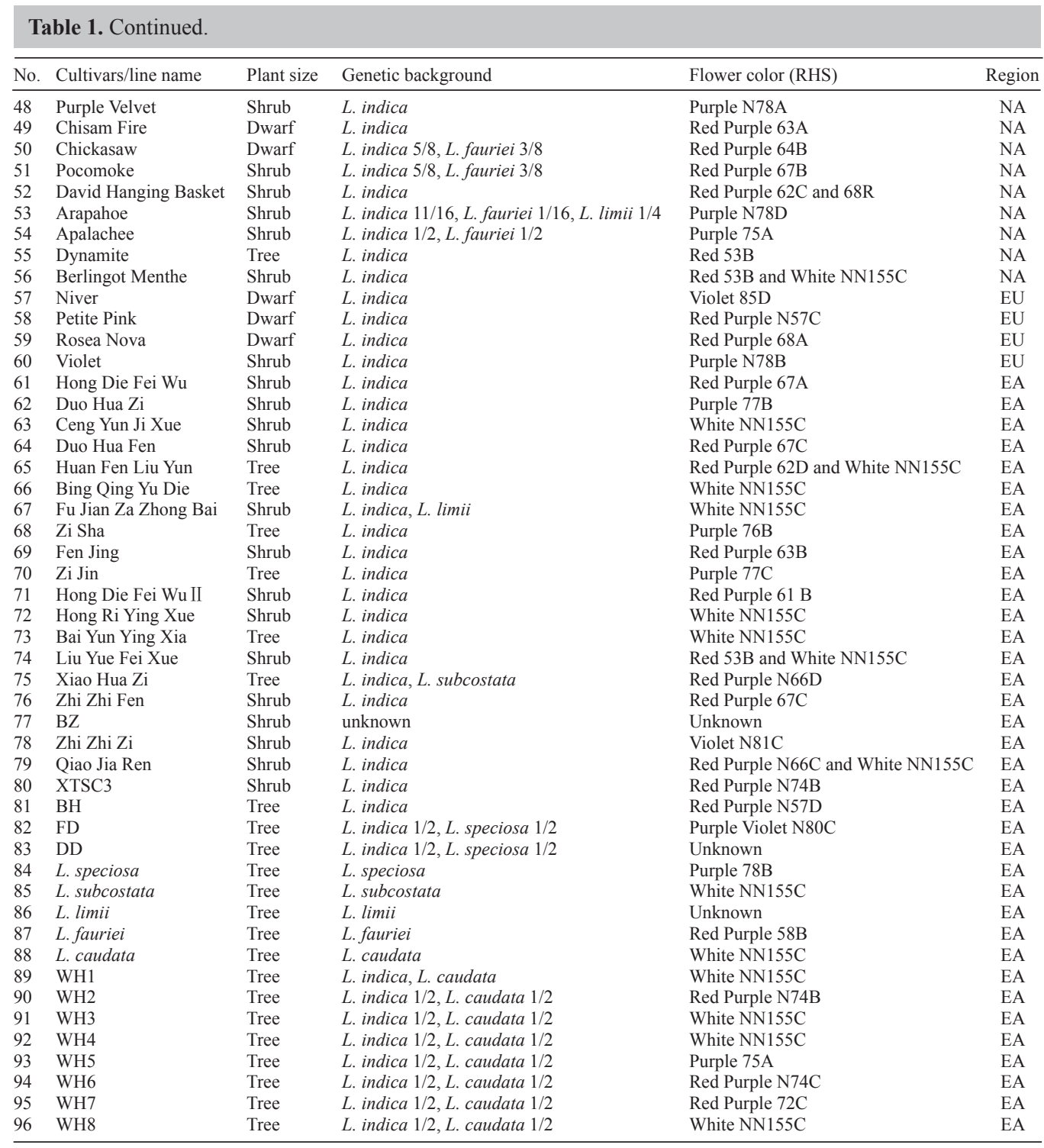

RHS $=$ Royal Horticulture Society; NA $=$ North American; EU = Europe; EA = East Asia. Some pedigree information refers to Wang et al. (2011).

\section{DNA extraction}

Total genomic DNA was isolated from young leaf tissues, using the FastDNA kit (TianGen) and following the manufacturer protocol. DNA concentrations were estimated with Smart Ladder (TianGen) on a $1 \%(\mathrm{w} / \mathrm{v})$ agarose gel containing Gel Red at $0.1 \mu \mathrm{g} / \mathrm{mL} 1 \mathrm{X}$ TAE buffer, with bands visualized under UV light (Zhu et al., 2011). 


\section{SSR screening and analysis}

A total of 28 SSR primers were synthesized based on published information (Wang et al., 2010, 2011; Cai et al., 2011). Primers 29 and 30 were designed by Primer Premier 5.0 (Palo Alto, Canada) from the sequence data provided by GenBank. These primers were prescreened on eight randomly selected genotypes to select optimal primers for further analysis. The details of the nucleotide sequences of SSR primers are shown in Table 2.

\begin{tabular}{|c|c|c|c|c|c|}
\hline Locus & $\begin{array}{c}\text { GenBank } \\
\text { accession No. }\end{array}$ & Primer sequence $\left(5^{\prime}-3^{\prime}\right)$ & Repeat & $\operatorname{Tm}\left({ }^{\circ} \mathrm{C}\right)$ & $\begin{array}{c}\text { Allele } \\
\text { size (bp) }\end{array}$ \\
\hline SSR1 & GQ402050 & $\begin{array}{l}\text { F: }<\text { FAM }>\text { AGAGAAAGAGAGGAGCGGGAGT } \\
\text { R: ACCTTCTTCCCCAATTCAATCC }\end{array}$ & $(\mathrm{GT})_{6} \mathrm{GC}(\mathrm{GT})_{6}$ & 55 & 213 \\
\hline SSR2 & GQ402053 & $\begin{array}{l}\text { F: <FAM }>\text { ACGTTTAGCACACCGGTACTGT } \\
\text { R: GGAAGCACATCACTATGGCAAG }\end{array}$ & $(\mathrm{GT})_{7}$ & 55 & 181 \\
\hline SSR3 & GQ402058 & $\begin{array}{l}\text { F: <FAM>GGTGGAGATGCTAACAAGCAAG } \\
\text { R: GGATTTTTGCTGTAGGGTGATT }\end{array}$ & $(\mathrm{TG})_{16}$ & 55 & 161 \\
\hline SSR4 & GQ402073 & $\begin{array}{l}\text { F: < FAM }>\text { CCCTCATACCTTCTTTATCAAGTCA } \\
\text { R: ATCCCCACAAAATCTCTCCTTC }\end{array}$ & $(\mathrm{AC})_{13}$ & 55 & 215 \\
\hline SSR5 & GQ402085 & $\begin{array}{l}\text { F: }<\text { FAM }>\text { TGGGATCGATGCTATTAATGTTG } \\
\text { R: TACACCAATTCACACCTCCACTC }\end{array}$ & $(\mathrm{GT})_{8}$ & 55 & 207 \\
\hline SSR6 & GQ402087 & $\begin{array}{l}\text { F: < FAM>ACATGGCTCCCATCACACAG } \\
\text { R: CAGGGGATTCTTGTTTTGCTTT }\end{array}$ & $(\mathrm{AC})_{6}$ & 55 & 160 \\
\hline SSR7 & GQ424407 & $\begin{array}{l}\text { F: }<\text { ROX }>\text { CTCTCAAATGACCCTCTT } \\
\text { R: TTGAGTAATAACAAGTCCC }\end{array}$ & $(\mathrm{AAAG})_{5}$ & 48 & 255 \\
\hline SSR8 & GQ424409 & $\begin{array}{l}\text { F: }<\text { HEX }>\text { GAGTTCATGCAGTTAGGT } \\
\text { R: ATATCGGATTTATCTTCC }\end{array}$ & $(\mathrm{AAG})_{6}$ & 48 & 130 \\
\hline SSR9 & GQ424414 & $\begin{array}{l}\text { F: }<\text { ROX }>\text { GGAAGAGGGATTGGAACC } \\
\text { R: TCTCACTGAAAGAAACTA }\end{array}$ & $(\mathrm{GA})_{5} \mathrm{G}(\mathrm{GGA})_{4}$ & 48 & 134 \\
\hline SSR 10 & GQ424415 & $\begin{array}{l}\text { F: }<\text { HEX >ACGGTAGATAAGGTGAGC } \\
\text { R: GGTTTCGTATCGTCGTAG }\end{array}$ & $(\mathrm{CT})_{9} \mathrm{~T}(\mathrm{CTGT}) \mathrm{GT}(\mathrm{CTGT})_{4}$ & 52 & 166 \\
\hline SSR11 & GQ424416 & $\begin{array}{l}\text { F: }<\text { HEX > TACTGGGTATCCGTTTCT } \\
\text { R: ACAGGTGCATTTACTTCC }\end{array}$ & $(\mathrm{CT})_{6} \mathrm{CC}(\mathrm{CT})_{12}$ & 50 & 317 \\
\hline SSR 12 & GQ438235 & $\begin{array}{l}\text { F: }<\text { FAM }>\text { TTCTGACCCAGCAGTAAA } \\
\text { R: CGTATCTCATCTGTAGCGTA }\end{array}$ & $(\mathrm{AGGT})_{4}$ & 50 & 138 \\
\hline SSR13 & GQ438241 & $\begin{array}{l}\text { F: }<\text { HEX }>\text { GGGAATTTGGGATATGGA } \\
\text { R: TAAAGAAACGACCGAGCC }\end{array}$ & $(\mathrm{AAAG})_{5}$ & 52 & 179 \\
\hline SSR14 & GQ248217 & $\begin{array}{l}\text { F: }<\text { HEX }>\text { GTCACAGGTTACCGAATC } \\
\text { R: ATGTAAATGGTGAGGAGG }\end{array}$ & $(\mathrm{AATC})_{5}$ & 50 & 253 \\
\hline SSR15 & GQ248218 & $\begin{array}{l}\text { F: }<\text { ROX }>\text { TTCTTGTCTTGGGTATCGC } \\
\text { R: GAGCCAGTATTGTCTTCACG }\end{array}$ & $(\mathrm{CCTT})_{7}$ & 50 & 228 \\
\hline SSR16 & GQ248219 & $\begin{array}{l}\text { F: }<\text { HEX }>\text { TTCTTCCACTTCCTCCTT } \\
\text { R: CAGCCCACATTAACTTTT }\end{array}$ & $(\mathrm{AG})_{12}$ & 50 & 204 \\
\hline SSR17 & GQ248220 & $\begin{array}{l}\text { F: <FAM>AAAGACGCAGAAGGATGG } \\
\text { R: CGATTAGTTTCAGCTCGT }\end{array}$ & $(\mathrm{AG})_{20}$ & 50 & 420 \\
\hline SSR18 & GQ248228 & $\begin{array}{l}\text { F: }<\text { FAM }>\text { GGACCAGATTGTAAATGC } \\
\text { R: CTGCTCCTAATATCAGTGTC }\end{array}$ & $(\mathrm{CT})_{15}$ & 50 & 289 \\
\hline SSR19 & GQ248233 & $\begin{array}{l}\text { F: }<\text { HEX }>\text { TAGTCCATTCATGTCAAG } \\
\text { R: GGATTCACCAAACTACTT }\end{array}$ & $(\mathrm{AG})_{14}$ & 52 & 246 \\
\hline SSR20 & GQ424383 & $\begin{array}{l}\text { F: <FAM>TTTGGTGGTAGTGGGAGT } \\
\text { R: GTGTCTGCATGGCTGTAA }\end{array}$ & $(\mathrm{CTGT})_{6}$ & 54 & 305 \\
\hline SSR21 & GQ424384 & $\begin{array}{l}\text { F: }<\text { ROX }>\text { CCTAACAAGAAAGGAACAG } \\
\text { R: TTTCAGGACATCAGCACC }\end{array}$ & $(\mathrm{AG})_{11}$ & 60 & 144 \\
\hline SSR22 & GQ424386 & $\begin{array}{l}\text { F: }<\text { HEX }>\text { CCTCCTCCTGCCACTCCTCT } \\
\text { R: CCCGTCGTCTCCTCAGTTCTC }\end{array}$ & $(\mathrm{AAG})_{4} \mathrm{ATG}(\mathrm{AAG})_{2}$ & 54 & 194 \\
\hline SSR23 & GQ424397 & $\begin{array}{l}\text { F: }<\text { FAM }>\text { CAACAGTAAAATTGGAGC } \\
\text { R: AGTAGTGATTCGGGTGGA }\end{array}$ & $(\mathrm{CTTT})_{7}$ & 55 & 144 \\
\hline SSR24 & HQ677290 & $\begin{array}{l}\text { F: }<\text { HEX >ATCAATGTCCACAACAACTTGCC } \\
\text { R: GGTTTGGTCGATTTGTTCAGTTA }\end{array}$ & $(\mathrm{AAG})_{7}$ & 55 & 158 \\
\hline
\end{tabular}

Continued on next page 


\begin{tabular}{|c|c|c|c|c|c|}
\hline Locus & $\begin{array}{c}\text { GenBank } \\
\text { accession No. }\end{array}$ & Primer sequence $\left(5^{\prime}-3^{\prime}\right)$ & Repeat & $\operatorname{Tm}\left({ }^{\circ} \mathrm{C}\right)$ & $\begin{array}{c}\text { Allele } \\
\text { size (bp) }\end{array}$ \\
\hline SSR25 & HQ677242 & $\begin{array}{l}\text { F: }<\text { FAM }>\text { TACACTCCCTCCCATTCAGATTGT } \\
\text { R: GCTGCCTGAATCAGTGAAGAGAGT }\end{array}$ & $(\mathrm{AGA})_{7}$ & 55 & 97 \\
\hline SSR26 & HQ677282 & $\begin{array}{l}\text { F: }<\text { HEX }>\text { ACGTATCAACCGAATGACCACTTT } \\
\text { R: GAATTCAAAGCTCAAGTGGGGAC }\end{array}$ & $(\mathrm{TTC})_{10}$ & 55 & 137 \\
\hline SSR27 & HQ677293 & $\begin{array}{l}\text { F: }<\text { HEX }>\text { GTCTCACTCTCTCAACTCAAGGGC } \\
\text { R: TGAGAAAGAATTTTTCTGAACCG }\end{array}$ & $(\mathrm{TCT})_{6}$ & 55 & 137 \\
\hline SSR28 & HQ677322 & $\begin{array}{l}\text { F: }<\text { HEX }>\text { ATGTACACCCGAAACCCTTTAGGT, } \\
\text { R: TCCATGTCTTGTCACAGCCTCTAC }\end{array}$ & $(\mathrm{TCT})_{7}$ & 55 & 131 \\
\hline SSR29 & GQ402090 & $\begin{array}{l}\text { F: }<\text { FAM }>\text { TGTCACTTCTGCAAATAT } \\
\text { R: AACTACTGCCATCATACT }\end{array}$ & $(\mathrm{TC})_{7}$ & 50 & 229 \\
\hline SSR30 & GQ402051 & $\begin{array}{l}\text { F: <FAM>GTGTTGGGAGTCAGATGG } \\
\text { R: ACAGCCGTTCGACATTAA }\end{array}$ & $(\mathrm{AC})_{6}$ & 48 & 191 \\
\hline
\end{tabular}

$\mathrm{Tm}=$ melting temperature.

The forward primers were synthesized with an additional 18 nucleotides from the M13 universal primer appended to the 5'-end (Schuelke, 2000). The SSR reactions were performed in a $10-\mu \mathrm{L}$ reaction volume that contained $20 \mathrm{ng}$ genomic DNA, $5 \mu \mathrm{L} 2 \mathrm{X}$ Taq PCR Master Mix (Biomiga), and $50 \mathrm{ng}$ each forward and reverse primer. The M13 universal primer was labeled either with a blue (FAM), green (HEX), or red (ROX) fluorescent tag (Sangon, Shanghai, China).

PCR began with denaturation at $94^{\circ} \mathrm{C}$ for 3 min, followed by 30 cycles of PCR amplification, each consisting of $30 \mathrm{~s}$ at $94^{\circ} \mathrm{C}$ for denaturation, $30 \mathrm{~s}$ at $48^{\circ}-60^{\circ} \mathrm{C}$ (primer specific) for annealing, and $30 \mathrm{~s}$ at $72^{\circ} \mathrm{C}$ for extension, and a final extension of $72^{\circ} \mathrm{C}$ for $5 \mathrm{~min}$. The PCR products $(0.5 \mu \mathrm{L})$ with different fragment sizes and different fluorescent labels were pooled and combined with $9 \mu \mathrm{L}$ Hi-Di formamide and 0.5 $\mu \mathrm{L}$ LIZ-500 (Applied Biosystems, USA) size standard and analyzed on an ABI3730xl DNA Analyzer (Applied Biosystems). The GeneMapper v4.0 software (Applied Biosystems) was used to determine the polymorphic information content (PIC).

\section{Data analysis}

The summary statistics reflected the genetic diversity level, including the observed number of alleles per locus $\left(N_{\mathrm{A}}\right)$, PIC, Shannon's information index $(I)$, observed heterozygosity $\left(H_{\mathrm{O}}\right)$, expected heterozygosity $\left(H_{\mathrm{E}}\right)$, Nei's genetic distance, F-statistics $\left(F_{\mathrm{ST}}, F_{\mathrm{IS}}\right.$, and $\left.F_{\mathrm{IT}}\right)$ (Wright, 1969) and gene flow $\left(N_{\mathrm{m}}\right)$, which were calculated using POPGENE version 1.31 (Yeh et al., 1999). We carried out analysis of molecular variance (AMOVA) to partition the genetic variance between regions, and between individuals within regions, using the Arlequin version 2000 software (Schneider et al., 2000). Genetic distances between individuals were calculated based on shared allele distance to create a matrix. The cluster results of 96 genotypes were conducted by PowerMarker version 3.25 (Liu and Muse, 2005), and dendrograms were viewed with MEGA 4 (Tamura et al., 2007).

\section{RESULTS}

\section{Allelic diversity at SSR loci}

One third of 30 SSR loci were developed from L. caudata, and the rest were devel- 
oped from $L$. indica. Of these $30 \mathrm{SSR}$ loci, dinucleotide repeats and tetranucleotide repeats both represented $40 \%$, and the remaining six SSR loci $(20 \%)$ were trinucleotide repeats. The 30 SSR markers that generated 275 alleles were used to estimate the genetic diversity among 96 accessions. The $N_{\mathrm{A}}$ revealed by each marker ranged from 4 to 15 , with an average of 9 per marker (Table 3). The PIC value ranged from 0.25 (SSR22) to 0.86 (SSR3), with an average of 0.63 .

\begin{tabular}{|c|c|c|c|c|c|c|c|c|c|c|}
\hline Locus & $N_{\mathrm{A}}$ & PIC & $I$ & $H_{\mathrm{o}}$ & $H_{\mathrm{E}}$ & Nei' & $F_{\text {IS }}$ & $F_{\text {IT }}$ & $F_{\mathrm{ST}}$ & $N_{\mathrm{m}}$ \\
\hline SSR1 & 10 & 0.76 & 1.78 & 0.65 & 0.79 & 0.78 & -0.03 & 0.03 & 0.06 & 3.83 \\
\hline SSR2 & 12 & 0.73 & 1.81 & 0.42 & 0.75 & 0.75 & 0.47 & 0.51 & 0.06 & 3.66 \\
\hline SSR3 & 15 & 0.86 & 2.29 & 0.73 & 0.87 & 0.87 & 0.01 & 0.06 & 0.05 & 5.15 \\
\hline SSR4 & 11 & 0.58 & 1.34 & 0.28 & 0.63 & 0.63 & 0.48 & 0.53 & 0.08 & 2.83 \\
\hline SSR5 & 15 & 0.81 & 2.04 & 0.75 & 0.83 & 0.83 & 0.13 & 0.17 & 0.05 & 4.55 \\
\hline SSR6 & 11 & 0.85 & 2.11 & 0.78 & 0.87 & 0.86 & 0.02 & 0.07 & 0.05 & 5.12 \\
\hline SSR7 & 8 & 0.45 & 1.06 & 0.32 & 0.47 & 0.46 & 0.33 & 0.37 & 0.07 & 3.31 \\
\hline SSR8 & 8 & 0.56 & 1.22 & 0.25 & 0.62 & 0.62 & 0.61 & 0.63 & 0.05 & 5.21 \\
\hline SSR9 & 12 & 0.78 & 1.99 & 0.64 & 0.81 & 0.80 & 0.23 & 0.28 & 0.07 & 3.59 \\
\hline SSR10 & 10 & 0.75 & 1.75 & 0.81 & 0.78 & 0.77 & -0.06 & 0.01 & 0.07 & 3.52 \\
\hline SSR11 & 9 & 0.65 & 1.47 & 0.38 & 0.71 & 0.70 & 0.39 & 0.41 & 0.03 & 8.23 \\
\hline SSR12 & 4 & 0.36 & 0.76 & 0.45 & 0.39 & 0.38 & -0.19 & -0.16 & 0.03 & 8.60 \\
\hline SSR13 & 5 & 0.59 & 1.18 & 0.64 & 0.66 & 0.66 & -0.13 & -0.01 & 0.11 & 1.99 \\
\hline SSR14 & 5 & 0.51 & 1.05 & 0.49 & 0.57 & 0.57 & 0.05 & 0.11 & 0.06 & 4.00 \\
\hline SSR15 & 8 & 0.63 & 1.44 & 0.71 & 0.66 & 0.66 & 0.03 & 0.05 & 0.03 & 8.58 \\
\hline SSR16 & 11 & 0.63 & 1.54 & 0.19 & 0.66 & 0.66 & 0.63 & 0.64 & 0.02 & 10.29 \\
\hline SSR17 & 15 & 0.84 & 2.14 & 0.81 & 0.86 & 0.86 & -0.13 & -0.04 & 0.08 & 2.78 \\
\hline SSR18 & 8 & 0.72 & 1.60 & 0.45 & 0.76 & 0.75 & 0.36 & 0.37 & 0.02 & 10.37 \\
\hline SSR19 & 14 & 0.79 & 2.05 & 0.32 & 0.81 & 0.81 & 0.59 & 0.61 & 0.03 & 7.60 \\
\hline SSR20 & 4 & 0.46 & 0.91 & 0.18 & 0.55 & 0.55 & 0.76 & 0.76 & 0.03 & 8.55 \\
\hline SSR21 & 7 & 0.26 & 0.64 & 0.15 & 0.27 & 0.27 & 0.35 & 0.43 & 0.12 & 1.76 \\
\hline SSR22 & 6 & 0.25 & 0.59 & 0.26 & 0.26 & 0.26 & -0.05 & 0.02 & 0.07 & 3.53 \\
\hline SSR23 & 6 & 0.43 & 0.95 & 0.32 & 0.46 & 0.46 & 0.23 & 0.33 & 0.13 & 1.61 \\
\hline SSR24 & 7 & 0.61 & 1.34 & 0.69 & 0.64 & 0.64 & 0.01 & 0.05 & 0.04 & 5.99 \\
\hline SSR25 & 10 & 0.71 & 1.66 & 0.73 & 0.74 & 0.73 & -0.01 & 0.02 & 0.03 & 9.04 \\
\hline SSR26 & 10 & 0.81 & 1.97 & 0.65 & 0.83 & 0.83 & 0.13 & 0.15 & 0.02 & 10.98 \\
\hline SSR27 & 6 & 0.60 & 1.28 & 0.41 & 0.64 & 0.64 & 0.46 & 0.50 & 0.07 & 3.27 \\
\hline SSR28 & 15 & 0.73 & 1.75 & 0.39 & 0.76 & 0.76 & 0.42 & 0.45 & 0.05 & 5.18 \\
\hline SSR29 & 8 & 0.74 & 1.71 & 0.67 & 0.78 & 0.77 & 0.18 & 0.19 & 0.02 & 14.98 \\
\hline SSR30 & 5 & 0.59 & 1.20 & 0.75 & 0.64 & 0.64 & -0.22 & -0.13 & 0.07 & 3.41 \\
\hline Mean & 9 & 0.63 & 1.49 & 0.51 & 0.67 & 0.67 & 0.20 & 0.24 & 0.05 & 4.50 \\
\hline
\end{tabular}

$N_{\mathrm{A}}=$ observed number of alleles; PIC = polymorphic information content; $I=$ Shannon's information index; $H_{\mathrm{O}}=$ observed heterozygosity; $H_{\mathrm{E}}=$ expected heterozygosity; $N_{\mathrm{m}}=$ gene flow.

The $I$ computed in our experiment was 1.49 and ranged from 0.59 (SSR22) to 2.29 (SSR3). Nei's genetic distance for the SSR loci ranged from 0.26 (SSR22) to 0.87 (SSR3), with an average of 0.67 . The mean $H_{\mathrm{O}}(0.51)$ was lower than the $H_{\mathrm{E}}(0.67)$. Of the $30 \mathrm{SSR}$ loci, the mean $F_{\mathrm{ST}}$ was 0.05 , while $F_{\text {IS }}$ and $F_{\text {IT }}$ were 0.20 and 0.24 , respectively. $N_{\mathrm{m}}$ varied from 14.98 (SSR29) to 1.61 (SSR23), with an average of 4.50.

\section{Cluster analysis and genetic diversity}

The genetic relationships between the accessions were determined based on shared allele distance for the 275 fragments. Overall, the 96 accessions were divided into three major clusters: A, B, and C (Figure 1). 


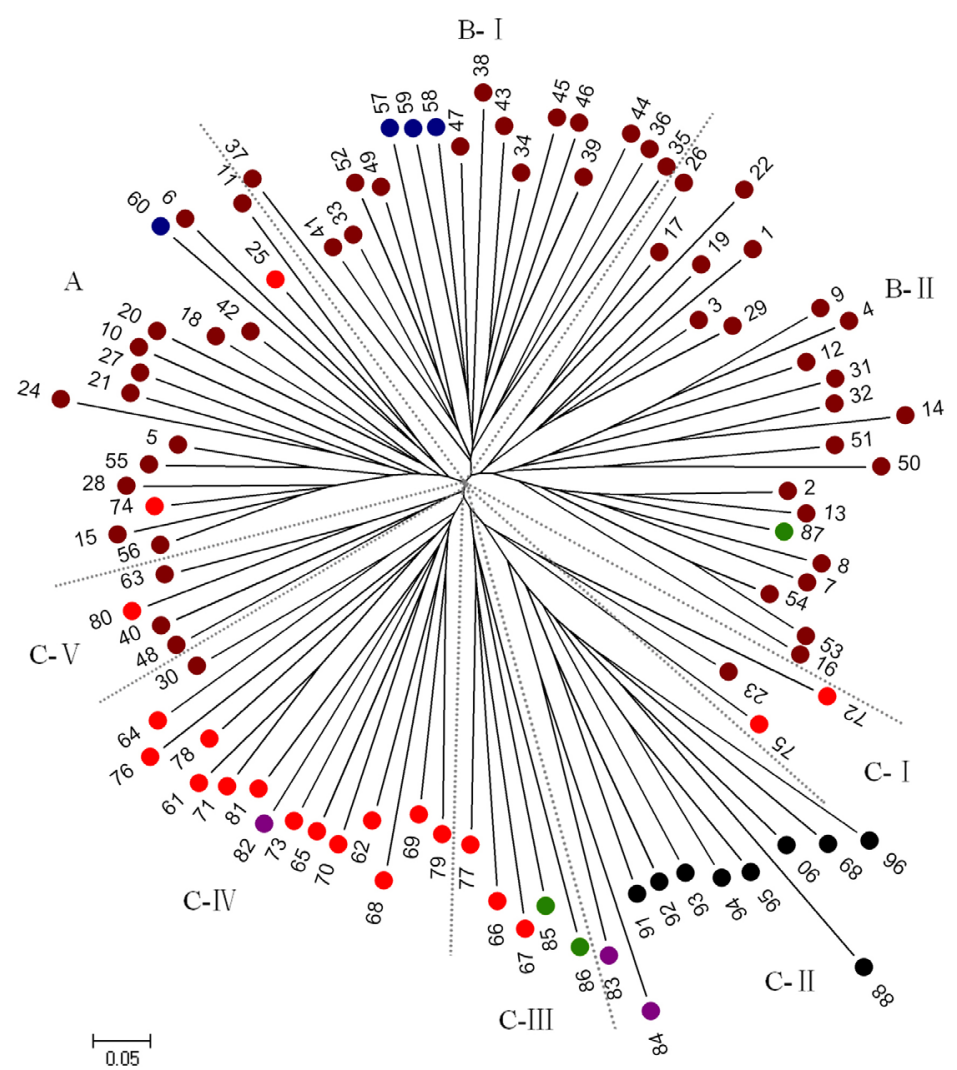

Figure 1. Cluster analysis of 96 individuals. Brown represents the cultivars collected from North American, blue represents the cultivars collected from Europe, red represents the cultivars from China, green represents the species (Lagerstroemia subcostata, L. limii, L. fauriei), purple represents L. speciosa and its interspecific hybrids, black represents $L$. caudata and its interspecific hybrids.

Cluster A comprised 17 cultivars: 14 cultivars collected from North America, No. 60 from Europe, and Nos. 25 and 74 from East Asia. Among the 17 cultivars, Nos. 10 and 20 had a common parent $L$. fauriei (No. 87). The rest of the cultivars originated from $L$. indica and the flower colors were red or purple.

Cluster B was composed of $L$. fauriei with 40 cultivars, of which three (Nos. 57, 58 and 59) were from Europe; the other cultivars were collected from North America. Two subclusters of cluster B were named B-I and B-II. Cluster B-I comprised 18 genotypes. This subcluster corresponded to growth habit; most were dwarf and weeping cultivars. Cluster B-II contained 20 of the 22 cultivars, which were interspecific hybrids between L. fauriei (No. 87) and L. indica.

Cultivars in Cluster $\mathrm{C}$ were cultivated in China except for Nos. 23, 30, 40, and 48, and originated from $L$. indica. All the interspecific hybrids shared the genetic background of $L$. indica, and were grouped in this cluster. Cluster $\mathrm{C}$ was further divided into five sub-clusters. Cluster C-IV comprised 15 cultivars: 14 Chinese cultivars, which were long-term selections from cultivated population of L. indica and No. 82. Clusters C-I and V contained Nos. 72, 75 
and 80 from China and Nos. 23, 30, 40, and 48 from North America, respectively. Clusters II and III consisted of four species and their hybrids. L. speciosa (No. 84) and No. 83 are closely related, because $L$. speciosa was one of the direct parents of No. 83. Accession Nos. 89 to 96 shared a common parent, L. caudata (No. 88) in cluster C-II. In cluster C- III, Nos. 77, 66, and 67 were all cultivars from China and clustered with L. subcostata (No. 85) and L. limii (No. 86).

\section{DISCUSSION}

SSR primers developed from both $L$. caudata and $L$. indica produced clean amplification of PCR products with the expected allele sizes from 96 genotypes, indicating that a high proportion of SSRs from related species can be used in amplifying crape myrtles (Cai et al., 2011). The mean number of alleles per SSR locus (9) detected in this study was higher than that reported by Wang et al. (2011) (6.6) from 57 L. indica cultivars, five L. fauriei cultivars and 37 interspecific hybrids and higher than that detected by Cai et al. (2011) (5.8) from 50 Chinese crape myrtle cultivars. The higher number of alleles per locus in our study could reflect the differences between genotypes and the co-dominant SSR markers used in genetic diversity analysis. Compared to other studies on the genetic diversity of crape myrtle using AFLP and RAPD (Pooler, 2003; Yang et al., 2004; Gu et al., 2010), SSR markers showed a higher efficiency of polymorphism evaluation. The SSR loci that produced a higher number (12-15) of alleles, such as SSR2, SSR3, SSR5, SSR9, SSR17, SSR19, and SSR28, revealed a high gene diversity (PIC value), which ranged from 0.73 to 0.86 per locus. The average PIC among dinucleotide repeats was 0.7 , while the PIC for tri- and tetranucleotide repeats was 0.67 and 0.55. In general, the SSRs with dinucleotide repeats showed higher allele diversity than did tri- and tetranucleotide repeats, and a direct relationship exists between marker information content and the number of repeat units (Innan et al., 1997; Ali et al., 2008; Cai et al., 2011). The PIC values in our study indicated that these markers are useful for molecular research, for differentiating genotypes and clustering them for genetic diversity analysis (Narasimhamoorthy, 2008).

The $H_{\mathrm{E}}(0.67)$ was higher than the $H_{\mathrm{O}}(0.51)$, which suggests that heterozygosity is deficient for these loci, possibly because of the presence of null alleles at these loci. In such cases, heterozygous plants carrying one null allele may be scored as homozygous for the readable allele (Dias et al., 2008). The hierarchical AMOVA indicated different levels of genetic variance among populations and among individuals within populations. Only $5 \%\left(F_{\mathrm{ST}}\right)$ of the overall variation was the result of differences between the three geographic regions. The higher gene flow observed in our study might have been related to the sampling of populations over a larger geographic area (Mehes, 2009) and because the cultivars came from different regions. In our study, the results indicated a higher genetic diversity compared to other studies (Nan et al., 2003; Sereno et al., 2006; Ali et al., 2008), which probably resulted from the allogamy of the Lythraceae. Thus, the results in this study demonstrated that SSR markers are effective tools for improving the genus taxonomy of Lagerstroemia, especially in solving the confusion surrounding the exact number of species in this genus (Rinehart and Pounders, 2010).

In the cluster analysis, nearly all the crape myrtle cultivars were clustered together, while the Lagerstroemia species and interspecific hybrids were grouped together, which was similar to the results based on SSR markers of Rinehart and Pounders (2010), Wang et al. (2011), and Cai et al. (2011). There were several exceptions, i.e., the L. indica cultivars Nos. 
19 and 32 clustered with L. fauriei (No. 87) while Nos. 66 and 77 clustered with L. subcostata (No. 85) or L. limii (No. 86). Nos. 19 and 32 were purchased from a commercial source. When they were propagated, transported, and sold, mislabeling could have occurred because of their similar flower color and growth habit (Wang et al., 2011). On the other hand, Nos. 19, 32, 66, and 77 lack a full and certain description and may be hybrids, although they were labeled as L. indica.

The cluster analysis showed that cultivars from the same geographic regions tended to group together (Zhu et al., 2011). Cultivars from North America mainly grouped in Clusters $\mathrm{A}$ and $\mathrm{B}$, while Chinese cultivars grouped in Cluster $\mathrm{C}$. There was an interesting exception in that Nos. 15, 56, and 74 are from different geographic regions but grouped together. Interestingly, according to the morphological database, they have many similar traits, such as the same flower color (Red 53B and White NN155C) and plant size (shrub). Based on this result, we concluded that the three cultivars may have a similar genetic background.

Within clusters, there are some sub-clusters corresponding to growth habit. Nos. 34 and 39, which originated from a bud mutation of No. 38, are dwarf cultivars. Likewise, Nos. $33,35,36,37,43,46$, and 49, which originated from seedling selection by Chopin from a checklist (http://www.usna.usda.gov/Research/Herbarium/Lagerstroemia/), are dwarf and weeping cultivars. The hybrids, namely Nos. 1, 2, 3, 4, 7, 8, 9, 12, 13, 14, 16, and 17, are trees or large shrubs, probably because they have the genetic background of L. fauriei. Clustering resulting from growth habit is likely to reflect shared pedigrees (Dirr et al., 2005; Wang et al., 2011) or the same breeding method.

Most cultivars in Cluster A originated from $L$. indica, and the flower colors were red or purple. Zhang et al. (2008) reported that the red or purple flower color is probably the result of specific anthocyanin accumulation that was inherited from $L$. indica. White flower color is associated with $L$. fauriei. Generally, the higher percentage of $L$. fauriei in a cultivar's genetic background, the lighter the flower color will be (Wang et al., 2011). Our results showed a similar trend as in the report of Wang. Nos. 2, 7, 8, 13, 16, and 54 clustered closely with $L$. fauriei (No. 87), contained half or a quarter of the genetic material of L. fauriei in their background, and produced light lavender or pink flowers. The other cultivars in sub-cluster B-II that contained less genetic background from $L$. fauriei had dark lavender or pink flowers.

Among the five species, L. fauriei was clustered with North American cultivars because it was a parent of these cultivars. The remaining four species were clustered with the Chinese cultivars. Eight interspecific hybrids (Nos. 89 to 96) were hybrids of $L$. caudata (No. 86) and Chinese cultivars, and they had different levels of fragrance because $L$. caudata is an aromatic species. L. speciosa and L. caudata were clustered together, while L. subcostata and L. limii were clustered closely. Species and their interspecific hybrids formed new cultivar groups, indicating that these accessions represent new resources for breeding programs.

Several genotypes that shared a common parentage were clustered into different groups instead of being clustered together. For example, Nos. 10 and 20 (Cluster A) and No. 23 (Cluster C-I) share L. fauriei in their parentage but were not grouped in Cluster B-II. Similarly, No. 82 (Cluster C-IV) has the parentage of L. speciosa (Cluster C-II), but they were not clustered together, which demonstrated that genetic relationships based on molecular markers do not always agree with the results estimated by pedigree information, because of unrealistic assumptions for estimating the co-ancestry coefficient (Ali et al., 2008).

In conclusion, based on the results of our study, the use of microsatellite markers was 
highly informative for Lagerstroemia. Long time geographic isolation seems to have led to significant genetic differentiation among Lagerstroemia germplasm resources. The phylogenetic relationship and genetic variation of Lagerstroemia germplasm will provide a rich source of materials for the selection of appropriate parents for breeding programs.

\section{ACKNOWLEDGMENTS}

Research supported by the Fundamental Research Funds for the Central Universities of China (\#JD2010-1) and the 12th Five Years Key Programs for Science and Technology Development of China (\#2012BAD01B07).

\section{REFERENCES}

Ali ML, Rajewski JF, Baenziger PS and Gill KS (2008). Assessment of genetic diversity and relationship among a collection of US sweet sorghum germplasm by SSR markers. Mol. Breed. 21: 497-509.

Barkley NA, Roose ML, Krueger RR and Federici CT (2006). Assessing genetic diversity and population structure in a Citrus germplasm collection utilizing simple sequence repeat markers (SSRs). Theor. Appl. Genet. 112: 1519-1531.

Bohn M, Utz HF and Melchinger AE (1999). Genetic similarities among winter wheat cultivars determined on the basis of RFLPs and SSRs and their use for predicting progeny variance. Crop Sci. 39: 228-237.

Brickell C (1996). Encyclopedia of Garden Plants. Macmillan Press, New York, 250-252.

Cai M, Meng R, Pan HT and Gao YK (2010). Isolation and characterization of microsatellite markers from Lagerstroemia caudata (Lythraceae) and cross-amplification in other related species. Conservat. Genet. Resour. 2: 89-91.

Cai M, Pan HT, Wang XF and He D (2011). Development of novel microsatellites in Lagerstroemia indica and DNA fingerprinting in Chinese Lagerstroemia cultivars. Sci. Hortic. 131: 88-94.

Dias PMB, Julier B, Sampoux JP and Barre P (2008). Genetic diversity in red clover (Trifolium pratense L.) revealed by morphological and microsatellite (SSR) markers. Euphytica 160: 189-205.

Dirr MA, Waters V and Kardos J (2005). New Protected Woody Plant Introductions from the University of Georgia. Department of Horticulture, University of Georgia, Athens. Available at [http://www.canr.org/Dirr\%20 WoodyPlts-05.pdf]. Accessed November 27, 2010.

Egolf DR (1967). Four new Lagerstroemia indica L. cultivars. -'Catawba', 'Conestoga', 'Potomac' and 'Powhatan'. Baileya 15: 7-13.

Egolf DR (1981). 'Muskogee' and 'Natchez' Lagerstroemia. HortScience 16: 576-577.

Egolf DR (1986). 'Acoma', 'Hopi', 'Pecos' and 'Zuni' Lagerstroemia. HortScience 21: 1250-1252.

Egolf DR (1987). 'Apalachee', 'Comanche', 'Lipan', 'Osage', 'Sioux' and 'Yuma' Lagerstroemia. HortScience 22: 674.

Egolf DR (1990). 'Choctaw’ Lagerstroemia. HortScience 25: 992-993.

Egolf DR and Andrick AO (1978). The Lagerstroemia Handbook/Checklist: A Guide to Crape Myrtle Cultivars. American Association of Botanical Gardens and Arboreta, Las Cruces.

Gu CH, Bao ZY, Wang SX and Zhang QX (2010). AFLP analysis on the genetic relationship of Lagerstroemia subcostata, Lagerstroemia limii and 37 cultivated varieties. Mol. Plant Breed. 8: 730-735.

Innan H, Terauchi R and Miyashita NT (1997). Microsatellite polymorphism in natural populations of the wild plant Arabidopsis thaliana. Genetics 146: 1441-1452.

Liu K and Muse SV (2005). PowerMarker: an integrated analysis environment for genetic marker analysis. Bioinformatics 21: 2128-2129.

Mehes M, Nkongolo KK and Michael P (2009). Assessing genetic diversity and structure of fragmented populations of eastern white pine (Pinus strobus) and western white pine (P. monticola) for conservation management. J. Plant Ecol. 2: 143-151.

Nan P, Shi SH, Peng SL and Tian CJ (2003). Genetic diversity in Primula obconica (Primulaceae) from Central and Southwest China as revealed by ISSR markers. Ann. Bot. 91: 329-333.

Narasimhamoorthy B, Saha M, Swaller CT and Bouton JH (2008). Genetic diversity in switchgrass collections assessed by EST-SSR markers. Bioenerg. Res. 1: 136-146.

Pooler MR (2003). Molecular genetic diversity among 12 clones of Lagerstroemia fauriei revealed by AFLP and RAPD markers. HortScience 38: 256-259.

Pooler MR (2006). 'Arapaho' and 'Cheyenne' Lagerstroemia. HortScience 41: 855-856. 
Pounders C (2007). Evaluation of interspecific hybrids between Lagerstroemia indica and L. speciosa. HortScience 42: $1317-1322$.

Rinehart TA and Pounders CT (2010). Estimating diversity among Lagerstroemia species and hybrids using SSR markers. Acta Hort. 885: 285-290.

Schneider S, Roessli D and Excoffier L (2000). Arlequin ver. 2.000: A Software for Population Genetic Data Analysis. Genetics and Biometry Laboratory. University of Geneva, Geneva.

Schuelke M (2000). An economic method for the fluorescent labeling of PCR fragments. Nat. Biotechnol. 18: 233-234.

Sereno ML, Albuquerque PSB, Vencovsky R and Figueira A (2006). Genetic diversity and natural population structure of cacao (Theobroma cacao L.) from the Brazilian Amazon evaluated by microsatellite markers. Conservat. Genet. 7: $13-24$

Subramanyam K, Muralidhararao D and Devanna N (2009). Genetic diversity assessment of wild and cultivated varieties of Jatropha curcas (L.) in India by RAPD analysis. Afr. J. Biotechnol. 8: 1900-1910.

Tamura K, Dudley J, Nei M and Kumar S (2007). MEGA4: Molecular evolutionary genetics analysis (MEGA) software version 4.0. Mol. Biol. Evol. 24: 1596-1599.

Wang XW, Dean D, Wadl P and Hadziabdic D (2010). Development of microsatellite markers from crape myrtle (Lagerstroemia L.). HortScience 45: 842-844.

Wang XW, Wadl PA, Pounders C and Trigiano RN (2011). Evaluation of genetic diversity and pedigree within crape myrtle cultivars using simple sequence repeat markers. J. Am. Soc. Hort. Sci. 136: 116-128.

Wright S (1969). Evolution and the Genetics of Populations. Vol. 2. The Theory of Gene Frequencies. University of Chicago Press, Chicago.

Yang YL, Zhang YD, Zhang XY and Lei XH (2004). Study on genetic diversity of wild Lagerstroemia from Baokang. J. Huazhong Agr. Univ. 23: 667-670.

Yeh FC, Yang RC and Boyle T (1999). POPGENE (Microsoft Windows-Based Freeware for Population Genetic Analysis) Version 1.31. Centre for International Forestry Research, University of Alberta, Edmonton.

Zhang C, Chen X, He T, Liu X, et al. (2007). Genetic structure of Malus sieversii population from Xinjiang, China, revealed by SSR markers. J. Genet. Genomics 34: 947-955.

Zhang J, Wang LS, Gao JM, Shu QY, et al. (2008). Determination of anthocyanins and exploration of relationship between their composition and petal coloration in crape myrtle (Lagerstroemia hybrid). J. Integr. Plant Biol. 50: 581-588.

Zhang QX (1991). Studies on cultivars of crape myrtle (Lagerstroemia indica) and their uses in urban greening. J. Beijing For. Univ. 13: 57-66.

Zhu RR, Gao YK, Xu LJ and Zhang QX (2011). Genetic diversity of Aquilegia (Ranunculaceae) species and cultivars assessed by AFLPs. Genet. Mol. Res. 10: 817-827. 